\title{
SOME REMARKS CONCERNING POLISH JAPONISME MOVEMENT FROM THE MODERNIST ERA
}

Aneta Pawłowska

University of Lodz, Poland

Data recepción: 2017/01/27

Data aceptación: 2017/06/05

Contacto autora: aneta.pawlowska@uni.lodz.pl

ORCID: https://orcid.org/0000-0003-2847-4403

\section{ABSTRACT}

Polish Japonisme, i.e. Japanese art as a source of inspiration in the work of the Polish painters and printmakers of early modernist period (late 19th and early 20th centuries).

The article will present well-known Polish artists such as Olga Boznańska, Julian Fałat, Wojciech Weiss, Leon Wyczółkowski, Satnisław Wyspiański, and Jan Stanisławski and his talented students. In juxtaposing the work of Polish artists of the Young Poland period with selected examples of Japanese ukiyo-e woodblock prints and silk paintings (by such masters as Hokusai, Hiroshige and Utamaro) and sculptures and artistic handicraft, I will analyse this phenomenon from a 21 st-century perspective.

This new approach encourages the reader to make comparisons, to look - almost as a matter of course - for similarities and differences between Polish and Japanese arts, and, in revealing the clear and deep analogies between the two cultures, to engage in an intercultural dialogue.

Keywords: Polish art, Japonisme, ukiyo-e prints

If we take a close look at the phenomenon of Japonisme', which emerged in the European artistic centers in the final part of the $19^{\text {th }}$ century, from the perspective of our $21^{\text {st }}$ century, it remains one of the most extraordinary and significant aspects in the history of modern art. The influence of Japanese art, which - according to Edmond de Goncourt (1822-1896) - revolutionized the vision of the European peoples and the numerous consequences of Japonisme have been emphasized on a number of occasions, with comparisons to the impact of Antiquity on the art of the Renaissance. It was also interpreted in a similar way much later by several famous Polish art researchers such as Mieczysław Wallis (1895-1975)² and Maria Rzepińska (1914- 1993). In her influential book entitled, Historia koloru $w$ dziejach malarstwa europejskiego [The history of color in the history of European painting], Rzepińska contends:

Ever more evident in Europe, the new Japanese aesthetic of flat silhouettes, of colored and black calligraphic lines, was - toutes proportions gardees - as significant to modern painting as ancient sculpture was to the Renaissance painters. It provided inspiration, and its approach to color and composition satisfied many a painter's desire to refresh and change their artistic vision ${ }^{3}$.

In my opinion it is hard not to agree with her point of view!

Regarding the latest approaches and recent discussions on the subject of the Polish artists inspired by the Japanese culture, one could say that this topic was under scrutinized consideration of many Polish researchers such as: Łukasz Kossowski (1986, 2016)4, Anna Król (2011), Małgorzata 
Martini (2016)6, Jerzy Malinowski (2001, 2013)7, Piotr Spławski (2013) ${ }^{8}$ and Agnieszka Kluczewska-Wójcik (2013, 2014, 2016)9.

Despite certain minor differences, all above mentioned scientists were in agreement that the penetration of the Japanese aesthetic fueled the modernist movement in the Polish visual art. However most of the researchers claimed also that the Polish interest in Japanese art was brought to Poland via France, and not directly from the Land of the Rising Sun.

\section{Japanese art as a source of inspiration for European painters}

In the second half of the $19^{\text {th }}$ century, trade routes from Japan were finally opened for the first time in two hundred years. Along with many other goods, Japanese art was one of the main things which was imported into the western world. The art from a country which has been isolated for such a long time was extremely fascinating for many Europeans as well as Americans. The dark outlines, the rich interesting colors and the unique techniques began to inspire the artists from the west, who began to implement gradually these inspirations which they gained from Japanese art into their own works. The people of France decided to give this new semimovement the name "Japonisme". This French term was used to describe a range of European borrowings from Japanese art. It was coined in 1872 by a French critic, collector and printmaker Philippe Burty "to designate a new field of study - artistic, historic and ethnographic", encompassing decorative objects with Japanese designs (similar to $18^{\text {th }}$ century - Chinoiserie), paintings of scenes set in Japan, and Western paintings, prints and decorative arts influenced by Japanese aesthetics. The two major places of opportunity for introduction of Japanese art to spectators in Europe were the International Exhibition held in London (1862) and the Exposition Universelle organized in Paris (1867). Although the highest point of the "Japanese craze" in Paris came with the 1900 Expo, when works of classical Japanese paintings were shown, going back to the $7^{\text {th }}$ century, previously practically unknown in Euro$\mathrm{pe}^{10}$. Simultaneously, several merchants in Paris and London actively imported Japanese artworks, mainly ukiyo-e ${ }^{11}$. From 1870s onward, Japanese art fascinated many prominent European artists such as Charles Baudelaire, James Abbott McNeill Whistler, Aubrey Beardsley, Édouard Manet, Edgar Degas, Claude Monet, Pierre-Auguste Renoir, Mary Cassatt, Henri de Toulouse-Lautrec, Vincent van Gogh, Paul Gauguin, Gustav Klimt and Claude Debussy, to name just a few ${ }^{12}$. All of these artists were especially affected by the lack of perspective and shadow, the flat areas of strong rich color, and the compositional freedom gained by placing the subject off-centre, mostly with a low diagonal axis to the background.

The indisputable centre of Japonisme in the $19^{\text {th }}$ century was without a doubt - Paris. The French capital was the principal place of business of the famous art dealer and collector Siegfried (Samuel) Bing (1838-1905), involved in popularization of broadly defined Japanese art through his gallery called L'Art Nouveau and Le Japan Artistique magazine published between 1888 and 1891'13. In 1886, such an admired Dutch painter as Vincent Van Gogh (1853-1890) began exploring Japonisme, and by 1887 , he had created several works reflecting the bold colors and simple lines known in this style of art. This fascination compelled him to write to his brother Theo:

\footnotetext{
If we study Japanese art, we discover a man who is undeniably wise, philosophical and intelligent, who spends his time - doing what? Studying the distance from the earth and the moon? No! Studying the politics of Bismarck? No! He studies... a single blade of grass. But this blade of grass leads him to draw all the plants - then the seasons, the grand spectacle of landscapes, finally animals, then the human figure. That is how he spends his life, and life is too short to do everything. So come, isn't what we are taught by these simple Japanese, who live in nature as if they themselves were flowers, almost a true religion? And one cannot study Japanese art, it seems to me, without becoming merrier and happier, and we should turn back to nature in spite of our education and our work in a conventional world ${ }^{14}$.
}

One can assume that what attracted the admiration of European artists in Japanese art was the new way of perceiving and capturing reality, and its reflection in pictorial composition. It was manifested by sparse use of the means of expression, skilful synthetization and simplification of forms, 
flat stains of color and supple decorative lines, in short: by sophisticated simplicity.

\section{The beginnings of research concerning Japonisme in Poland}

A similar kind of vivid interest concerning Japan, which initially started in Europe and USA around 1860s, reached also Poland in the last decades of the $19^{\text {th }}$ century. Born at the meeting of two divergent cultures, the trend called in Polish japońszczyzna or japonizm became a catalyst for tremendous changes in the Polish art.

However in Poland, the study of Japonisme is still a relatively new development, it should be emphasized that the topic of Japanese inspirations in the work of the Polish Modernists was often addressed in press publications from 1900 on. To illustrate this, one needs only to refer to Felix Jasieński (1861-1929) an eminent Polish art collector and art critic who was active at the beginning of the $20^{\text {th }}$ century. He wrote enthusiastically: "Wonderful land! Wonderful people! Wonderful art!" 15 and "If you surrender yourself to the charm of its [Japanese] art, you start to abominate Western art" ${ }^{16}$. Jasieński gathered together, for the very first time in Poland, a splendid collection of Japanese art works. His stay in Paris in the mid-1880s gave him a wonderful opportunity to become acquainted with the latest aesthetic trends. This experience made him even more ardent collector of oriental art. Even after his return to Poland around 1890, he continued purchasing oriental art works such as lacquer and ivory items, Japanese swords, paintings, textiles, and ukiyo-e through auctions and art dealers. At the same time, he made extraordinary effort to introduce Japanese art to Polish art collectors by organizing exhibitions and contributing many articles about Japanese art to major journals. In 1901 he published an influential book entitled Manggha. Promenades à travers les mondes, l'art et les idées ${ }^{17}$. The volume was meant as its author's ideological manifesto, in which he extols Japanese art and qualities, in his opinion, associated with it. Moreover Jasieński also used "Manggha" as his own nickname. His collection of oriental art, donated finally to the National Museum in Cracow in 1920, consisted of 15,000 objects in total including 6,000 Japanese works ${ }^{18}$.
In the second half of the $20^{\text {th }}$ century, the phenomenon of Japonisme was entirely excluded from the Polish researchers' field of interest. It was not until the beginning 1980s that the pioneering works which were conducted by Zofia Alberowa ${ }^{19}$ and kukasz Kossowski20 came out. Subsequent wider-scale studies of the subject were undertaken by the Manggha Museum of Japanese Art and Technology in Cracow ${ }^{21}$ only in 2005, through a long-term exhibition and publication project called Polish Japonism. Following Kossowski's and Manggha Museum publications, several artists have been identified by scholarship as influenced by Japonisme (e.g. Olga Boznańska, Jan Stanisławski, Stanisław Wyspiański, Wojciech Weiss, Julian Fałat and Leon Wyczółkowski).

\section{Modernism in Polish Art}

It is not an exaggeration to say that Japonisme reached its fullest intensity in Polish art during the Modernist period (1890-1914) and, similarly as other genres of the time, had its called "the happy hour" 22 then. It did happen with a delay of nearly twenty-five years compared to Western Europe, but the artistic scale of the phenomenon was truly extraordinary. Namely, not only did various trends - such as Secession (Art Nouveau), Symbolism, and proto-Expressionism - came to the foreground, but it also meant a meeting of a number of artistic individualities, and a creation of works that served as manifestoes ${ }^{23}$. Nonetheless the most important trend connected with Japonism was a trend called Young Poland (Polish: Młoda Polska). This tendency was a result of a strong aesthetic opposition to the earlier ideas of Positivism which followed the suppression of the 1863 January Uprising against the occupying army of Imperial Russia. "Młoda Polska" promoted trends of Decadence, Neo-romanticism, Symbolism, Impressionism and Art Nouveau.

Most often Polish artists encountered the art of the Far East and the phenomenon of Japonisme while travelling or living abroad - in Paris, Munich, or Vienna - in the mid-1880s ${ }^{24}$. The list of significant artists who encountered Japanese art in such a way was headed by such recognized Japonistes as Leon Wyczółkowski, Wojciech Weiss, Józef Pankiewicz, Julian Fałat, Olga Boznańska, Karol Frycz, Jan Stanisławski, 
Ferdynand Ruszczyc, Witold Wojtkiewicz, Kazimierz Sichulski, and a few others. For the great majority of these artists Japonisme was never about the simple "quoting" of Japanese objects or just straightforward interpretation of the compositional principles collected from ukiyo-e woodblock prints. It was rather a genuine dialogue with another culture and spirituality, although the process of incorporating this different, revolutionary aesthetic did indeed begin with such depictions of Japanese objects of art or everyday use in Polish paintings. Therefore, the works from that period - primarily oil paintings, prints, and also ceramic products constitute an interesting resource for studying Polish Japonisme and its artistic significance.

A real cradle of the Polish Japonisme became Paris - many Polish painters, graphic artists, sculptors, potters and craftsmen discovered the art of Japan while studying or working there. The first critical and analytical writings on the Japanese art were elaborated there, as well. Lastly, Paris saw the inception of the great Japanese collections by Feliks Jasieński, Stanisław Dębicki (1866-1924) and Henryk Grohman (1862-1939). Japanese woodcuts, ceramics and textiles were recognized as the true works of art; their presence entire collections allowed artists to study the newly discovered esthetics ${ }^{25}$. Jasieński pended the promotion of the Japanese art into a fullblown battle for the Polish art.

\section{Women artists and Japonisme}

The earliest dated example of Japanese inspirations in Polish art is Japanese Woman (1879) painted by Maurycy Gottlieb (1856-1879), a Polish Jewish realist painter of the late Romantic period. Despite its title, the sitter is not Japanese. Her facial appearance points to either SoutheastAsian origin, or indeed she is an Orient-stylized European beauty. Such portraiture was common in contemporary European art; however, within Gottlieb's oeuvre it stands alone ${ }^{26}$. Thus the real history of Polish Japonisme begins with two great artist individualities: the women painters Anna Bilińska-Bohdanowiczowa (1857-1893) and Olga Boznańska (1865-1940), who went abroad to study at that time - Bilińska to the Academie Julian in Paris, Boznańska to Munich - and came into contact with Japanese art and its reception in the work of their contemporary artists. The first one - Bilińska, was extremely talented and thanks to her remarkable determination and consciousness of her artistic vocation she became the first Polish woman to obtain a professional, academic education. The artist's oeuvre isn't large and sadly only a few of her works remain in Polish collections. In the portrait of a Woman with a Japanese Parasol (1888), she combined a Japanese indigo kimono, an oriental parasol and a composition cropped in the manner of ukiyo-e with a Western beauty model with blonde hair. However, I think it is very likely that she absorbed Japanese-origin representational strategies not only directly from Japanese art. Artist whom Bilińska looked for inspiration was probably Claude Monet, in particular his masterpiece - La Japonaise, a portrait of Claude Monet's first wife Camille painted in 1876. It is important to emphasize that a lot of fashionable Parisian women in those days wore kimonos and decorated their homes with oriental furnishings, prints and objects d'art ${ }^{27}$.

Another prominent Polish female artist - Olga Boznańska was not interested in a prop or a quotation, or some literal travesty of a specific Japanese motif. She was fully aware of the multiplicity of possibilities in painting revealed by the art of the Far East, particularly by the woodblock print. Experienced profoundly and, over time, internalized, Japanese art became a constant point of reference for Boznańska's subsequent, increasingly original, work. Woodblock prints and their consequences for European painting, which had such a tremendous impact on her at the outset of her artistic career, never ceased to be a genuine system of reference for her work. As early as 1888, two years after Boznańska's arrival in Munich, she painted her first "Japanizing" compositions: Portrait of a Young Woman with a Japanese Parasol, and then the following year brought about masterly works in which Japanese aesthetics played a crucial role, among these $A$ Japanese Woman, The Florists and $A$ Brittany Girk2. There were no compositional solutions of comparable innovativeness in the Polish painting of that period. Boznańska presented the new concept of flattened space, based on vertical and horizontal divisions. The flatness is augmented by elimination of chiaroscuro mode- 
ling, while the scanty and sophisticated means of expression - carefully-conceived use of colors and simple structure - intensify the Japanese quality of the image. The new space was to be discovered by Polish modernists only in the early $20^{\text {th }}$ century. Boznańska is not interested in a prop or a quotation, or some travesty of a specific Japanese motif. She is fully aware of the multiplicity of possibilities in painting revealed by the art of the Far East, particularly by the woodblock print. Experienced profoundly and, over time, internalized, Japanese art became a constant point of reference for Boznańska's subsequent, increasingly original, work. Ukiyo-e prints and their consequences for European painting, which had such a tremendous impact on her at the outset of her artistic career, never ceased to be a genuine system of reference for her work.

Boznańska's fascinations with Japan probably culminated in the painting called $A$ Girl with Chrysanthemums of 1894, and these flowers were to appear in various pictures throughout the rest of the artist's life (fig. 1). A Girl with Chrysanthemums is considered a masterpiece of Polish Modernism. Boznańska broke away definitively from the $19^{\text {th }}$ century convention of depicting children, in decorative bright dresses indicative of wealth, with dolls and small bouquets of flowers. She created a disturbing image of a lonely, unknown girl, standing against a silver-grey wall, wearing a grey neutral dress, devoid of any embellishments, gazing intensely at the viewer. She is holding a pearl-white chrysanthemums in her clasped hands. In her bright face, surrounded with reddish-fair hair, her black eyes seem to glow. The eminent Polish art historian, Jerzy Malinowski pointed as a source of Boznańska's inspiration, the art and culture of Japan ${ }^{29}$. The chrysanthemum in the name of the most popular flower in Japan, the emperor's symbol (used in the name of the imperial throne), and also a symbol of happiness and longevity. The motif of a lady with chrysanthemums was often encountered in ukiyo-e woodblock prints. In the early $20^{\text {th }}$ century, photographs of small girls with chrysanthemums were extremely popular.

Although as I have stated, Boznańska's subject matter was not Oriental, she sometimes featured a woman holding a fan or umbrella (Self-Portrait

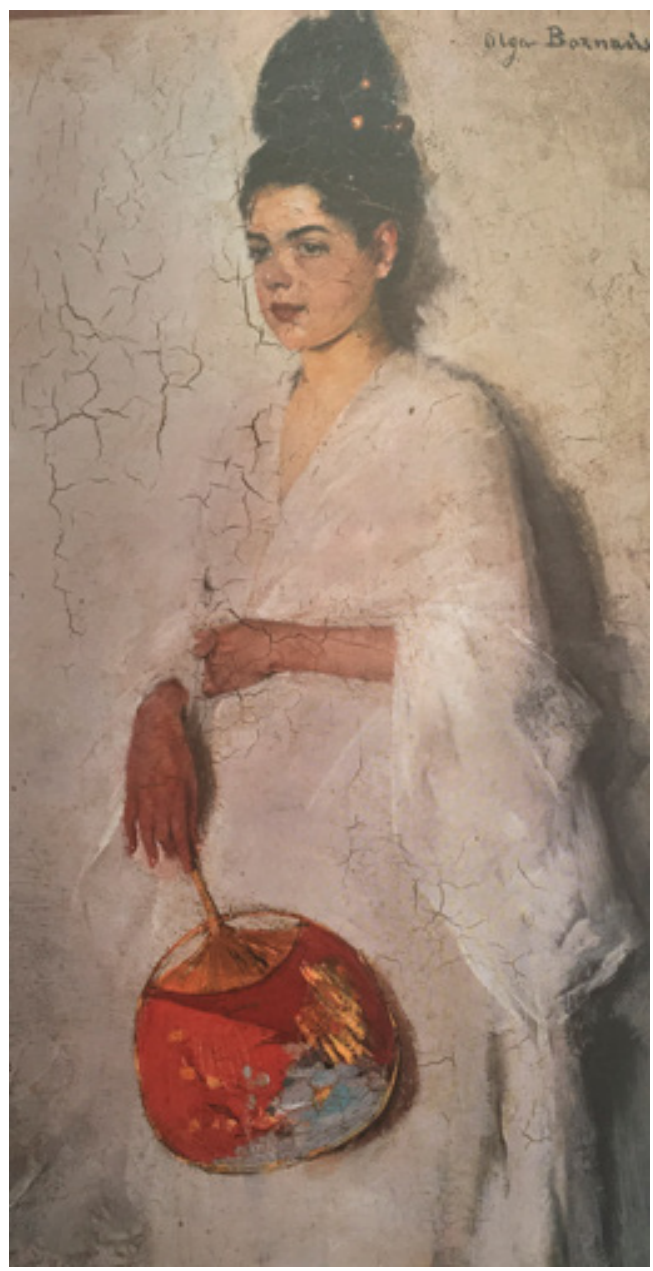

Fig. 1. Olga Boznańska, A Girl with Chrysanthemums, 1894, oil on cardboard, The National Museum in Cracow

with Japanese Parasol, A Japanese Woman) (fig. 2). In 1902 Boznańska painted with much bravura a picture entitled $A$ Dream ( or Portrait of a Woman in a Blue Kimono) which is a study of elegance and sophistication, inspired by bijin - beautiful women - depicted by the Japanese woodblock print masters: Utamaro and Hiroshige. Another painting made by Boznańska that year was Maternity, an example of interpretation of the composition found in ukiyo-e prints. In this work, the artist shows the figure from below, from a so call "frog's perspective" ${ }^{30}$. The women holding the child in her arm, the artist presents her as a fragment of a greater whole, her figure is cropped by the end of the image. The right 


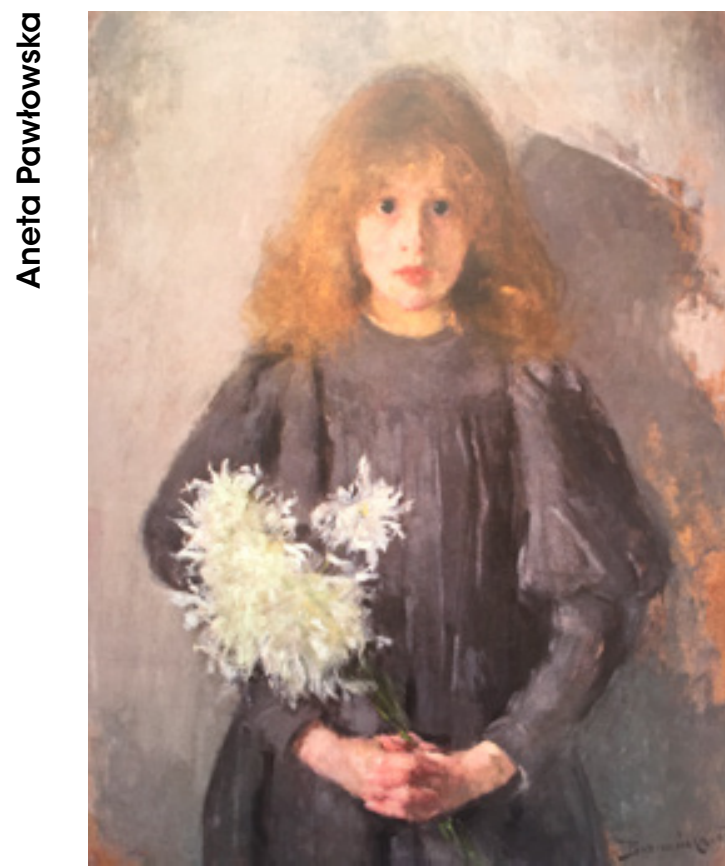

Fig. 2. Olga Boznańska, Japonese Woman 1889, oil on panel, The National Museum in Warsaw

section of the picture is empty, covered with blue paint.

\section{Polish Modernist landscapists and Japo- nisme}

In Modernism, landscape painting was considered a special and noble genre because it provided the most fertile ground for developing symbolic interpretation of reality. Its foundation was the romantic pantheistic belief in the unity of the structural design of the world. Another reason was the Industrial Revolution which altered the traditions of rural life, the old hierarchy of subjects to fell apart. Throughout Europe and Poland as well, landscape painting gained a new supremacy. Many revolutionary artists emerged and pushed the boundaries of landscape painting even further by making it both an emblematic and visual experience. The primary category describing the world was a mood of the "soul of nature". Surfacing in Young Poland's landscapes are motifs of the four elements - fire, wind, water and earth - painted many times and interpreted in sundry ways. Artists, regardless of the places

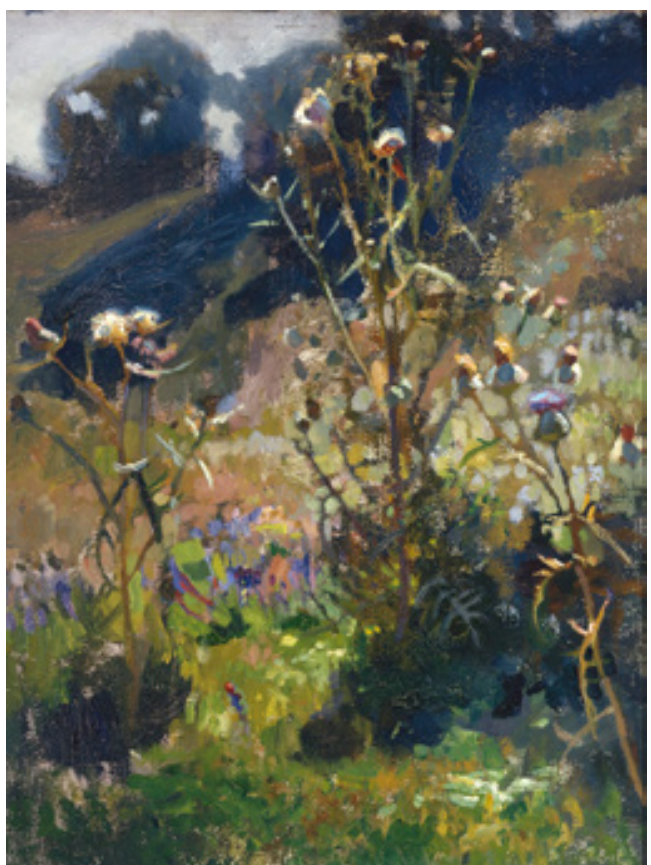

Fig. 3. Jan Stanisławski, Bodiaki [Thistles], 1885, oil on canvas, The National Museum in Cracow

they depicted, primarily conveyed and recorded moods, creating "soul landscapes" ${ }^{31}$. They preferred the transition times of the year (early spring and late autumn) and of the day (glowing sunsets and pale rosy dawns). Polish landscapists at the turn of the century apart from the influences of Impressionism and Post-Impressionism, Synthetism of the Pont-Aven School and Expressionism, also discovered Japonisme.

Much has been written about the Young Poland landscape, as has about its most prominent promoter Jan Stanisławski (1860-1907), but the crucial element of his art - Japonism - has been almost entirely ignored by Polish art historians for many years ${ }^{32}$.

The essence of Stanisławski's Japonism primarily comes down to the understanding of the sense of art and perception of nature. To him, just as to the Japanese masters, the ultimate goal of painting was to present the "spirit of objects", to reach the essence of things. The great admirer of Stanisławski's art, his contemporary, Polish poet Zenon Przesmycki, observed in the artist's treatment of nature some, disinterested 
veneration, religious as it were" ${ }^{33}$. The aim for Stanisławski was served by the symbolization of the depicted phenomena - a skill which the artist perfected throughout his whole period of creative activity, of over thirty years. One could notice in his paintings a nearly "academic" example of inspiration with the Japanese woodblock print - in the sophisticated image framing and composition, in the interplay of the foreground and the background and the planes between them, in the depiction of nature (series Bodiaki, 1885) (fig.3), in the unique treatment of optics (Mallows, Sun, Steppe), or in the fragmentary character of representation (Pustownia in Ukraine, 1902 and Cathedral in Siena, 1903). In the 1880 s and 1890 s, he travelled extensively and his sketchbooks filled up with drawings from Paris, Berlin, Dresden, Prague, Kraków, and various places in Ukraine ${ }^{34}$. As far as I am concerned the time that Stanisławski spent in Paris coincided with the pinnacle of interest in Japanese art. It was generally accessible not only for connoisseurs, artists and art dealers. Different pattern books, reproductions and albums were published, and it was relatively easy to purchase a popular landscape print series, for example by Katsushika Hokusai and Utagawa Hiroshige. In summary of the topic, we can say that Japonisme was seen not only as a fashion for Japanese goods, but also among Paris artists as a preference for the subject matter and style. Inevitably in many Stanisławski's paintings, all the major characteristics of Japanese aesthetics converge like in the focus of a lens. And his connections with the art, aesthetics and philosophy of Japan - although profound and diverse are all dominated by a similar attitude toward nature and reality. Very often key motifs (such as: small plants - bodiaki ${ }^{35}$, mallows, sunflowers) dominate drawings due to the simplification or even elimination of backgrounds. Regardless of the creative convention chosen - whether realistic or expressive - he remains faithful to the rules of composition principal for Japanese painting. Stanisławski was a master of simplification and synthetization, and the cannons of Japanese art were an instrument he used with real skill. He painted numerous oil sketches of landscapes from Ukraine, the Kraków and Podhale regions as well the areas surrounding Paris and Italian cities. When we look closely at his small picture ${ }^{36}$ one can see that simplification of Stanisławki's paintings is not a goal per se; it is intended to evoke suggestions; the painter must make his work simple because this is the only way to suggest the idea underlying his work to the viewer. Stanisławski created a "school" whose unique character has not been satisfactorily described in Polish art historiography yet, although he had more than 60 students. His apprentices such as Stanisław Kamocki, Henryk Szczygliński, Jan Talaga, Ivan Trush, and Teodor Ziomek - remained under his direct influence not only during their studies: some never really broke free from his influence ${ }^{37}$. They painted landscapes covering indicated by him themes: summer or winter orchards, thistles, sunflowers, riverbeds, and also common things, ordinary and well known, trying to endow them with some symbolic sense and simplification of Japanese art cannons.

Undoubtedly one of the most original and stimulating Polish painters who was active at the turn of the century was Leon Wyczółkowski (1852-1936). He first encountered art of the Far East during his several stays in Paris. He also visited the Expositions Universelles in 1878, 1889 and 1900 and gradually became a collector of Far Eastern art ${ }^{38}$. As a friend of Jasieński, Wyczółkowski was strongly influenced by him. He painted genre scenes, historical and symbolic compositions, still lives, portraits (e.g. Japanese women 1897) and landscapes. His masterpieces include pastel views of the Tatras and the East Carpathians. He left behind a rich artistic legacy, comprising of a variety of techniques (oil paintings, pastels, water-colours, drawings, prints) which are distinctive due to their novel workmanship as well as a collection of Far Eastern fabrics. Many of his pictures such as Flowers in the Window (1908) and Still Life (1905) are combination of Japonisme and French Impressionism. After 1902 Wyczółkowski turned almost exclusively to the graphic techniques as well as ink water-colour and pastel painting. Lithographic representations of winter landscapes from that period are regarded to be the pinnacle of Wyczółkowski's Japonisme. The artist was profoundly inspired by the depictions of nature by Hokusai and Hiroshige, and used them into many of his many paintings of Tatra Mountains landscapes. He created several series of Tatra masterpie- 
ces (e.g. Tatra Legends, Impressions of Zakopane, Morskie Oko) containing all the most important features of Japanese aesthetics and providing one of the most prominent examples of Polish Japonism ${ }^{39}$. The artist found a simple formula: "How is hugeness shown in a small format? (...) What you give is only a fragment, because the whole would reduce the hugeness." 40 This new, synthetic and fragmentary rendition of alpine motifs, amazed everyone.

The epithet "Cracow Japoniste" ascribed by the critic Antoni Potocki to Wojciech Weiss (18751950) was as appropriate in 1904 as it proved to be throughout the artist's long and extremely prolific career ${ }^{41}$. He studied at the Academy of Fine Arts in Cracow, but his aesthetics of Japonisme seemed rather international. The development of his Japonisme, to a certain extent was elicited by, his trip to Paris in 1897. Prior to that, however, his interest in Japanese art must have been ignited during his studies at Cracow Academy, where he attended Leon Wyczółkowski's class in 1896. It was Wyczółkowski, already drawing on Japanese art in his painting who passed the Japonisme enchantment to the young Weiss ${ }^{42}$. In Paris, he became influenced by the revolutionary Japanese aesthetic and by the discovery of unexpected compositional layouts in woodblock prints by such masters as Hokusai, Hiroshige and Utamaro. He familiarized himself with the famous collection of the de Goncourts brothers, put up for sale at the Hotel Drouot and visited art dealers offering Far Eastern prints and other arts and crafts, and probably purchased his first japonica ${ }^{43}$. His Japanese women. Rózia in Kimono (1901) was a distant echo of Whistler's portraits. It depicted attractive young European woman with a mysterious beauty in the original Japanese kimono. It is a clash of two different cultures combined in a romantic and balanced composition. Between 1897 and 1903, Weiss made several dozen small pictures in a variety of techniques - oils, watercolors, pastels, carbon, pencil - at the railway stations near Crakow in Płaszów and Strzyżów, depicting the tracks, sometimes the station buildings, and rows of cargo carriages. He showed them at different times of day, in changing weather: in summer heat, when the air seems to tremble in the glare of the sun; on a rainy day, before or after precipitation; in

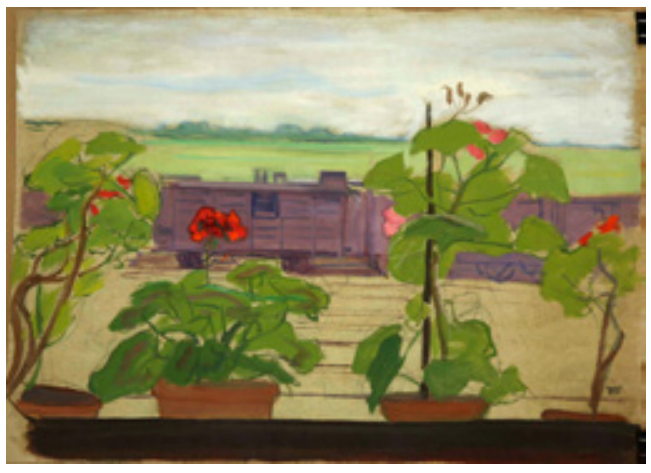

Fig. 4. Wojciech Weiss, Pelargoniums in the window, 1898, oil on paper, Wojciech Weiss Museum Foundation

fog, which merges into the smoke and billows of vapor ejected by the locomotives. The artist always composed his picture in the same manner, showing a section, a fragment of the industrial landscape, captured from above, incidentally, as if seen in passing, and adapting the principles of space construction drawn from Japanese art (fig. 4). The multiplied railway tracks vanish beyond the edge of the picture. These synthetic, sectional landscape studies are reduced to almost abstract layouts of track lines. When analyzing the Japanese inspirations in the artist's paintings, one can easily associates the solutions used in the depicted space, dominated by the diagonal arraignments of the tracks, with classical Japanese paintings, yamato-e, which illustrate emakimono scrolls, and the Japanese affection to horizontality.

\section{Fałat's sojourn in the Far East}

The only Polish artist of that generation who decided to undertake a trip to Japan was Julian Fafat (1853-1929) ${ }^{44}$. He is regarded as, one of Poland's foremost landscape and water-colour artists and the reformer of the Cracow Academy of Fine Arts. What really directed him onto the "Japanese path" was the period spent in Japan during his journey around the world. In 1885, during his journey around the world, he spent several weeks in that country; when approaching the Japanese government with a request for a temporary stay permit, he specified his intention to study art as the major reason ${ }^{45}$. In this context should be mentioned that it was very seldom in the $19^{\text {th }}$ century that artists decided to go to the 


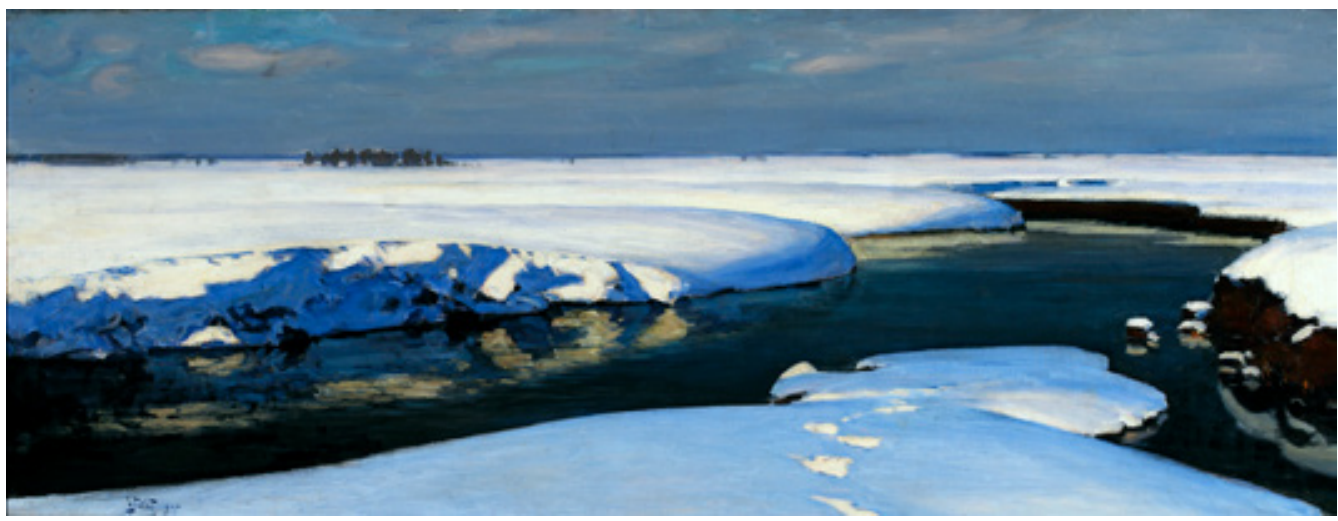

Fig. 5. Julian Fałat, Winter Landscape with a River, 1907, oil on cardboard, Julian Falat's Museum in Bystra

Far East. In that vein Oscar Wilde observed ironically: "In fact the whole of Japan is a pure invention. There is no such country, no such people." 46

Fałat brought back to Poland numerous objects including souvenirs of wooden, ivory and porcelain works, and a lot of photographs. He continued to purchase ukiyo-e and Japanese small sculptures in Europe ${ }^{47}$. His reception of Japan and Japanese art was full of enthusiasm and adoration, he wrote in his diary: "My admiration for Japan and the Japanese simply knows no bounds. I find explanations for all of their drawbacks (...)" 48 .

During the sojourn in the Far East Fałat painted many views from a ship (The Suez Canal, A View of Aden, A View of Singapore) and scenes taking place in seaports ( $A$ Singhalese Man Selling Bamboos, Malay Washerwoman in Singapore $)^{49}$. His masterly compositions from that scene Aboard the Ship and Merchants on the Island of Ceylon are made in two versions - one sketched as a note and then another one finished with care in water-colours, Impressionist in terms of aesthetics. Fałat was intrigued by both the exotic props (such as the Chinese parasol or the paper fan in the woman's hand, or the uchiwa-e fans decorated with irises and calligraphy) and the scene involving the merchants demonstrating their goods to the female passenger, languid in the tiresome heat ${ }^{50}$.

There can be no doubt that appreciation of Japan is seen in many Fałat's pictures, which he painted later on. Between 1895 and 1903 he produced a series of views of Cracow city in Poland captured from the same window of his studio. Painted at various times of the day and year, and in various techniques, these vedute follow ukiyo-e formal solutions such as elevated vantage point, objects cut off by the pictures edge and close-ups of certain elements. In some of these views the artist managed to convey the elusive ambience of the views in such a manner that they are evocative of the Zen category known as yûgen - hidden essence of profound grace and subtlety - the unachievable ideal for many artists $^{51}$. Their predominantly horizontally elongated formats, as well as their large sizes resemble Japanese folding screens or Chinese horizontal scrolls called emakiand.

Around 1901, Falat's work began to feature a motif of winter landscape with a creek meandering through snow-covered fields, rendered in oils, watercolors and pastels, exhibited under a variety of titles: Snow, A Winter Landscape, Creek in Snow and A Winter Motif (fig. 5). It is dominated by a panoramic capture of the landscape with one constant element of composition in the form of the straight horizon line dividing the picture into two zones. Some compositions are close to a square in shape, while other ones are more oblong. There is usually snow in the foreground, sometimes marked with animal tracks or enlivened with the silhouettes of birds flying by ${ }^{52}$. Fałat synthesizes the landscape in a masterly manner, simplifying its forms. He blows up the snow or the spurt almost to exaggeration - situating it in the foreground - and skips irrelevant details. In these winter landscapes, immersed in 
sunshine, he reproduces the palpability of snoweither its flakiness or weight during thaw-with a unique skill. All Fałat's paintings present a specific fragment of scenery, similarly as ukiyo-e masters, he creates a universal landscape, timeless, filled with the poetic perception of the world, characteristic to Japanese culture. To illustrate this, one needs only to refer to Utagawa Hiroshige ukiyo-e series Eight Vievs of Kanazawa Bay (1840?).

For today's art historians Falat is undoubtedly one of the most prominent "Japonist" among all Polish artists. Having experienced Japan firsthand, after his return to Poland Fałat became alert to the presence of Japonisme in Paris and Munich and in the works of other Polish painters. His synthetic simplifications of color and drawing; his expressiveness of the watercolor stain with his mastery of brushwork and even the exploitation of the white color paper (so characteristic of Fałat) all of this is a very original and very independent use of lessons learnt from Japanese art.

\section{Conclusion}

Japan provided many Polish artists with new and exciting ways of constructing the pictorial space, such as aerial perspective, horizontal, vertical and diagonal dimensionality, close-ups, the pars pro toto principle, fortuitous framing, composite formats, crating devices, truncation of objects, spatial divisions, and unorthodox formats.
Other Japanese lessons included planar quality of the pictorial surface, ornamental patterns and flat arabesques, repetition of motifs and rhythmically of composition, the use of bold outlines, tendency towards stylization and schematization, absence of shadows and rejection of illusionism. In addition to all of the above, the example of Japanese art enriched the iconographic vocabulary of western art by lending a remarkable range of motifs, as for example the ubiquitous wave.

To recapitulate, it can be concluded that late $19^{\text {th }}$ century Polish artists were not only familiar with Japanese aesthetics and Japonisme, but they also often successfully adapted them into their own work. Coming back to Poland from their scholarships abroad, they brought with them not only predilection for Japanese art but also some objects, or even whole collections, of Far Eastern art. It should be noted that the innovative works of Polish artists were so profuse not only due to such imported experience. An important role in the reception of the new aesthetic and forms was played by indigenous, Polish impulses as well. Another important point is that, besides occasional instances of incorporation of elements of Japanese art and Japan props into the Polish still lives, portraits and genre scenes, it was the landscape that proved the most cogent channel for the absorption and transformation of Japanese aesthetics, themes and pictorial conventions. 
NOTES

${ }^{1}$ I decided that I will use in the article alternately two terms: Japonisme (French term - first used from 1872) and English term - Japonism. Both terms describe the influence of Japanese art, fashion and aesthetics on Western art and culture.

${ }^{2}$ Mieczysław Wallis, Secesja, Warszawa 1984, p. 124.

${ }^{3}$ Maria Rzepińska, Historia koloru w dziejach malarstwa europejskiego, Kraków 1983, p. 526.

${ }^{4}$ Łukasz Kossowski, "O największym polskim Japończyku," in: Orient i orientalizm w sztuce, Warszawa 1986, Idem, and Małgorzata Martini, Wielka fala. Inspiracje sztuką Japonii w polskim malarstwie i grafice, Toruń 2016.

5 Anna Król, Japonizm polski, Kraków 2011.

6 Łukasz Kossowski, and Małgorzata Martini, op. cit.

${ }^{7}$ Jerzy Malinowski, "Podróż Juliana Fałata do Chin i Japonii w 1885," in: Orient w kulturze polskiej. Materiały z sesji jubileuszowej, Warszawa 2000, pp. 75-83; Idem, Introduction, in: Japanisms and Polish-Japanese Art Relations, eds. Jerzy Malinowski, Agnieszka Kluczewska-Wójcik, Toruń 2013, pp. 9-13.

${ }^{8}$ Piotr Spławski, Japonisme in Polish Pictorial Arts (1885 - 1939). PhD thesis, University of the Arts London 2013, http://ualresearchonline.arts. ac.uk/6205/ [Accessed: 06.06.2017].

9 Agnieszka Kluczewska-Wójcik, Collecting and promotion of the Japanese art in Poland at the turn of the 19th and 20th century, in: Japanisms and Polish-Japanese Art Relations..., pp. 165-176; Eadem, Feliks "Manggha” Jasieński i jego kolekcja w Muzeum Narodowym w Krakowie, Kraków 2014; Eadem, Japonia $w$ kulturze $i$ sztuce polskiej końca XIX i początków XX wieku, Toruń 2016.

${ }^{10}$ To see more: Eleonora Jedlińska, Powszechna Wystawa Światowa w Paryżu w 1900 roku. Splendory Trzeciej Republiki, Łódź 2015, pp. 161-162.

${ }^{11}$ About the art of Japanese woodblock printing, known as ukiyo-e ( eng. "pictures of the floating world") reed in: Frederick Harris, Ukiyo-e: The Art of the Japanese Print, Singapore 2010.

${ }^{12}$ To see more: Aneta Pawłowska, Julia Niewiarowska-Kulesza, Japonizm $w$ sztuce modernizmu. Obrazy przepływającego świata, Łódź 2016 and Gabriel P. Weisberg, The Orient Expressed. Japan's influence on western art 1854-1918, Jackson- San Antonio 2011.

${ }^{13}$ Gabriel P. Weisberg, Art Nouveau Bing: Paris Style 1900, New York 1986.

${ }^{14}$ Vincent van Gogh, Letter to Theo van Gogh, written 24 September 1888 in Aries; translated by Johanna van Gogh-Bonger, edited by Robert Harrison, no. 542. URL: http://webexhibits. org/vangogh/letter/18/542.htm.

${ }^{15}$ Feliks Jasieński, "Wystawa drzeworytów japońskich (u Krywulta w Warszawie)," Chimera, vol. 1, no. 1 (January 1901). pp. 172-174.

${ }^{16}$ Ibidem.

${ }^{17}$ The name of "Manggha" was taken from Katsushika Hokusai (17601849) largest work - Manga - 15 volumes of sketches done by him.

${ }^{18}$ To see more: Agnieszka Kluczewska-Wójcik, Feliks "Manggha" Jasieński..., pp. 67-89.

${ }^{19}$ Zofia Alberowa, O sztuce Japonii, Warszawa 1987 and Eadem, Sztuka japońska w zbiorach polskich, Warszawa 1988

${ }^{20}$ Zofia Alberowa, and Łukasz Kossowski, Inspiracje sztuka Japonii w malarstwie i grafice polskich modernistów. Katalog, Kielce 1981.

${ }^{21}$ The Manggha Museum of Japanese Art and Technology, created on the initiative of famous Polish film director - Andrzej Wajda and opened in 1994 as the Manggha Centre of Japanese Art and Technology, was a branch of the National Museum in Kraków for ten years, and at the same time the venue of the proactive activities of Andrzej Wajda and Krystyna Zachwatowicz's Kyoto-Krakow Foundation. In 2002, the Manggha Museum was visited by the Japanese Emperor Akihito and Empress Michiko, a great honour for us and a sign of recognition for our institution's efforts. In 2005, the Decision of the Minister of Culture granted the Manggha autonomy, changing its status to that of a state cultural institution, and since 2007 it has operated as a museum. In accordance with the Founders' idea, a special place was created in Kraków as 'a home for the collection of Japanese art' amassed mostly by Feliks 'Manggha' Jasieński, who donated it to the National Museum in 1920. The Collection of Far Eastern Art of the National Museum in Kraków was definitively deposited with the Manggha Museum in 2009. http://manggha.pl/en/aboutmuseum [Accessed: 13.01.2017].

22 The name "happy hour" of the Polish painting, during the Modernist period encompassing the conventional dates from 1890 to 1914, was not only the period when a group of extraordinary painters created their works but also when numerous excellent artworks were produced in a relatively short period of time, some of which, with full responsibil-ity, can be called the overused term 'masterpieces'. See: Maria Poprzecka, "Szczesliwa godzina” malarstwa polskiego. Malarstwo polskie około roku 1900 [The Happy Hour: Polish Painting around 1900], Eadem, Pochwala malarstwa. Stadia z historii i teorii sztuki, Gdansk 2000, p. 240.

${ }^{23}$ Symbolizm w malarstwie polskim 1890-1914, ed. Agnieszka Morawińska, Warszawa 1997, pp. 7-19.

${ }^{24}$ Throughout the whole $19^{\text {th }}$ century, from the collapse of Commonwealth of Two Nations (the political union of the Grand Duchy of Lithuania and the Kingdom of Poland) in 1795 until 1918, Poles had no longer a state of their own that would support the development of teaching and science. The 19th century saw the Polish schooling system in each partition gradually integrated into the occupying states' systems. The foreign rulers had no interest in developing the Polish scientific life and Polish schools. Such a policy prevailed in all three partitions but was the most hurtful in the Russian partition.

25 Agnieszka Kluczewska-Wójcik, Japonia w kulturze i sztuce polskiej..., pp. 118-129.

${ }^{26}$ Jerzy Malinowski, Malarstwo i rzeźba Żydów Polskich w XIX i XX wieku, t. l, Warszawa 2000, p. 80. 
${ }^{27}$ Aneta Pawłowska, Julia Niewiarowska-Kulesza, op. cit., pp. 31-32.

${ }^{28}$ About Japanese influences in the art of Olga Boznańska see: Łukasz Kossowski, Between japonaserie and japonisme. A few points on Japanese influences In the art. of Olga Boznańska, in: Olga Boznańska (1865-1940). Katalog, Warszawa 2015, pp. 89-99 and Anna Król, Manggha Boznańskiej. Inspiracje sztuką Japonii w malarstwie Olgi Boznańskiej, Kraków 2006.

29 Jerzy Malinowski, Malarstwo polskie XIX wieku, Warszawa 2003, p. 326.

30 Anna Król, Japonizm polski..., pp. 104-107.

${ }^{31}$ Wiesław Juszczak, Modernizm polski, in: Koniec wieku. Sztuka polskiego modernizmu 1890-1914, eds. Elżbieta Charazińska, Łukasz Kossowski, Warszawa 1996, pp. 13-27 and Krajobrazy: polskie malarstwo pejzażowe od Oświecenia do końca XX wieku, eds. Dorota Folga-Januszewska Barbara Brus-Malinowska, Warszawa 2000, pp. 200-210.

${ }^{32}$ To see more: Anna Król, Obraz świata, który przemija: inspiracje sztuką Japonii w malarstwie Jana Stanisławskiego i jego uczniówl An Image of a Floating World. Japanese Art Inspirations in the Paintings of Jan Stanisławski and his Students, Man- ggha Centre of Japanese Art and Technology, Kraków 2007.

${ }^{33}$ Zenon Przesmycki, "Sztuki plastyczne (Salon Krywulta)", Chimera, 1/1 (1901), p. 166.

${ }^{34}$ Anna Król, Obraz świata, który przemija..., pp. 53-63.

${ }^{35}$ Bodiaki is the common Ukrainian name of a group of flowering plants similar to thistle.

${ }^{36} \mathrm{~J}$. Stanisławski, due to his large overweight, did not paint large-scale canvases, it was too tiring to him.

${ }^{37}$ Anna Król, Obraz świata, który przemija..., p. 43.

${ }^{38}$ Anna Król, Japonizm polski..., pp. 180-189.

39 Łukasz Kossowski, Małgorzata Martini, op. cit., p. 213.

40 Maria Twarowska, Leon Wyczółkowski, Wrocław 1962, p. 29.

${ }^{41}$ Antoni Potocki, "Sztuka polska na Wystawie Światowej w Düsseldorfie", Sztuka 1904, p. 184 and Ten Krakowski Japończyk... http://kulturaonline.pl/ten,krakowski,japonczyk, galeria, 11225, 15073.html [Accessed: 12.12.2016]

${ }^{42}$ Wiesław Juszczak, Młody Weiss, Warszawa 1979, pp. 48-52.

43 Łukasz Kossowski, "O największym polskim Japończyku,"..., p. 101.
${ }^{44}$ To see more: Jerzy Malinowski, Julian Fałat, Warszawa 1985.

45 Thirty-five years later, he was followed by another Polish artist Karol Frycz, who went to China and Japan with a Polish diplomatic mission. He spending the period from 28 December 1919 to January 1921 in the Far East.

${ }^{46}$ Oskar Wilde, The Decay of Lying: An Observation, Cambridge 1889, p. 19.

${ }^{47} \mathrm{~J}$. Fałat collections may now be seen in the District Museum in BielskoBiała http://muzeum.bielsko.pl/pl/ historia-muzeum-falatowka [Accessed: 12.12.2016].

${ }^{48}$ Fałat 1987, p. 130

49 Jerzy Malinowski, "Podróż Juliana Fałata do Chin i Japonii w 1885," ... pp. 75-83.

${ }^{50}$ Ibidem, p. 101.

51 Yûgen is an important concept in traditional Japanese aesthetics, it suggests that beyond what can be said, but is not an allusion to another world. Andrew T. Tsubaki, "Zeami and the Transition of the Concept of Yūgen: a note on Japanese aesthetics," Journal of Aesthetics and Art Criticism 30/1(1971), pp. 55-67.

52 Anna Król, Japonizm polski..., pp. 126- 131. 


\section{REFERENCES}

Alberowa, Zofia and Łukasz Kossowski.1981. Inspiracje sztuka, Japonii w malarstwie i grafice polskich modernistów. Katalog, Kielce: Muzeum Narodowe w Kielcach.

Alberowa, Zofia. 1987. O sztuce Japonii. Warszawa: Wiedza Powszechna.

Alberowa, Zofia. 1988. Sztuka japońska w zbiorach polskich. Warszawa: Wydawnictwa Artystyczne i Filmowe.

Feliks Jasieński. 1901. "Wystawa drzeworytów japońskich (u Krywulta w Warszawie)." Chimera 1, no. 1 (January): 172-174.

Folga-Januszewska Dorota and Barbara BrusMalinowska, eds. 2000. Krajobrazy: polskie malarstwo pejzażowe od Oświecenia do końca XX wieku. Warszawa: Krajowa Agencja Wydawnicza.

Gogh, Vincent van. Letter to Theo van Gogh, written 24 September 1888 in Aries. no. 542. ed. Robert Harrison, translated by Johanna van Gogh-Bonger, Accessed December 12, 2016. http://webexhibits.org/vangogh/letter/18/542.htm.

Harris, Frederick. 2010. Ukiyo-e: The Art of the Japanese Print, Singapore: Tuttle Publishing.

J. Fałat collections may now be seen in the District Museum in Bielsko-Biała. Accessed December 12, 2016. http://muzeum.bielsko.pl/pl/historia-muzeum-falatowka

Jedlińska, Eleonora. 2015. Powszechna Wystawa Światowa w Paryżu w 1900 roku. Splendory Trzeciej Republiki, Łódź: Wydawnictwo Uniwersytetu Łódzkiego.

Juszczak, Wiesław. 1979. Młody Weiss, Warszawa: Wydawnictwa Naukowe PWN.

Juszczak, Wiesław. 1996. "Modernizm polski." In Koniec wieku. Sztuka polskiego modernizmu 1890-1914, edited by Elżbieta Charazińska and Łukasz Kossowski, 13-27. Warszawa: Muzeum Narodowe w Warszawie.

Kluczewska-Wójcik, Agnieszka. 2013. "Collecting and promotion of the Japanese art in Poland at the turn of the 19th and 20th century." In Japanisms and Polish-Japanese Art
Relations, edited by Jerzy Malinowski and Agnieszka Kluczewska-Wójcik, 165-176. Toruń: Marszałek.

Kluczewska-Wójcik, Agnieszka. 2014. Feliks "Manggha" Jasieński i jego kolekcja w Muzeum Narodowym w Krakowie, Kraków: Muzeum Narodowe w Krakowie.

Kluczewska-Wójcik, Agnieszka. 2016. Japonia w kulturze i sztuce polskiej końca XIX i początków XX wieku. Toruń: Wydawnictwo Tako.

Kossowski, Łukasz 1986. "O największym polskim Japończyku." In Orient i orientalizm w sztuce. Warszawa: Państwowe Wydawnictwo Naukowe.

Król, Anna. 2006. Manggha Boznańskiej. Inspiracje sztuką Japonii w malarstwie Olgi Boznańskiej, Kraków: Centrum Sztuki i Techniki Japońskiej "Manggha".

Król, Anna. 2011. Japonizm polski. Kraków: Muzeum Sztuki i Techniki Japońskiej "Manggha".

Malinowski, Jerzy. 1985. Julian Fałat, Warszawa: Wydawnictwa Naukowe PWN.

Malinowski, Jerzy. 2000. Malarstwo i rzeźba Żydów Polskich w XIX i XX wieku. vol. I, Warszawa: Wydawnictwa Naukowe PWN.

Malinowski, Jerzy. 2000. "Podróż Juliana Fałata do Chin i Japonii w 1885." In Orient w kulturze polskiej. Materiały z sesji jubileuszowe, 75-83. Warszawa: Muzeum Azji i Pacyfiku.

Malinowski, Jerzy. 2003. Malarstwo polskie XIX wieku, Warszawa: Wydawnictwo DiG.

Malinowski, Jerzy. 2013. "Introduction." In Japanisms and Polish-Japanese Art Relations, edited by Jerzy Malinowski and Agnieszka Kluczewska-Wójcik, 9-13. Toruń: Wydawnictwo Marszałek.

Muzeum Sztuki i Techniki Japońskiej Manggha w Europie - Galeria Dalekiego Wschodu. Accessed January 13, 2017http://manggha.pl/en/ about-museum.

Pawłowska, Aneta and Julia NiewiarowskaKulesza. 2016. Japonizm w sztuce modernizmu. Obrazy przepływającego świata. Łódź: Wydawnictwo Uniwersytetu Łódzkiego. 
Some remarks concerning polish japonisme movement from the modernist era

Poprzęcka, Maria. 2000 " "Szczesliwa godzina" malarstwa polskiego. Malarstwo polskie około roku 1900." In Pochwala malarstwa. Stadia z historii i teorii sztuki, Gdansk: Wydawnictwo słowo/obraz terytoria.

Potocki, Antoni. 1904. "Sztuka polska na Wystawie Światowej w Düsseldorfie." Sztuka 1: 184.

Przesmycki, Zenon. 1901. "Sztuki plastyczne (SaIon Krywulta)." Chimera, 1, no.1: 166.

Rzepińska, Maria. 1983. Historia koloru w dziejach malarstwa europejskiego. Kraków: Wydawnictwo Literackie.

Spławski, Piotr. 2013. Japonisme in Polish Pictorial Arts (1885 - 1939). PhD diss., University of the Arts London, http://ualresearchonline.arts. ac.uk/6205/ [Accessed: 06.06.2017].

Ten Krakowski Japończyk. Accessed December 12, 2016. http://kulturaonline.pl/ten, krakows ki,japonczyk,galeria, 11225,15073.html.
Tsubaki, Andrew T. 1971. "Zeami and the Transition of the Concept of Yūgen: a note on Japanese aesthetics." Journal of Aesthetics and Art Criticism 30, no. 1: 55-67. https://doi. org/10.2307/429574

Twarowska, Maria. 1962. Leon Wyczółkowski, Wrocław: Auriga.

Wallis, Mieczysław. 1984. Secesja. Warszawa: Arkady.

Weisberg, Gabriel P. 1986. Art Nouveau Bing: Paris Style 1900. New York: Metropolitan Museum Lib.

Weisberg, Gabriel P. 2011. The Orient Expressed. Japan's influence on western art 1854-1918. Jackson-San Antonio: Mississippi Museum of Art.

Wilde, Oskar. 1889. The Decay of Lying: An Observation. Cambridge: Brentano. 